\title{
Erratum: Allergic diseases and asthma in the family predict the persistence and onset-age of asthma: a prospective cohort study
}

Elina MS Paaso ${ }^{1,2}$, Maritta S Jaakkola ${ }^{1,3,5}$, Aino K Rantala ${ }^{1,4}$, Timo T Hugg ${ }^{1,4,5}$ and Jouni JK Jaakkola $1,2,4,5^{*}$

\section{Correction}

Following publication of our article [1] we noticed that the Acknowledgments section had been inadvertently omitted. The following acknowledgment should be added to the end of the article:

\section{Acknowledgments}

This study has been funded by the Research Foundation of the Pulmonary Diseases, the Finnish Anti-Tuberculosis Association Foundation, the Emil Aaltonen Foundation, the Academy of Finland (grant no. 129419 of SALVE research program and grants no. 138691 and no. 266314), the Ministry of Social Affairs and Health of Finland (grant no. STM/1523/2012) and the Yrjö Jahnsson Foundation.

\section{Author details}

${ }^{1}$ Center for Environmental and Respiratory Health Research, University of Oulu, Oulu, Finland. ${ }^{2}$ Respiratory Medicine Unit, Department of Medicine, Oulu University Hospital, Oulu, Finland. ${ }^{3}$ Respiratory Medicine Unit, Institute of Clinical Medicine, University of Oulu, Oulu, Finland. ${ }^{4}$ Public Health, Institute of Health Sciences, University of Oulu, Oulu, Finland. ${ }^{5}$ Medical Research Center Oulu, University of Oulu, Oulu, Finland.

Received: 3 February 2015 Accepted: 3 February 2015

Published online: 13 March 2015

\section{References}

1. Paaso EM et al. Allergic diseases and asthma in the family predict the persistence and onset-age of asthma: a prospective cohort study. Respir Res. 2014;15:152.

\footnotetext{
* Correspondence: jouni.jaakkola@oulu.fi

${ }^{1}$ Center for Environmental and Respiratory Health Research, University of Oulu, Oulu, Finland

${ }^{2}$ Respiratory Medicine Unit, Department of Medicine, Oulu University Hospital, Oulu, Finland

Full list of author information is available at the end of the article
}

Submit your next manuscript to BioMed Central and take full advantage of:

- Convenient online submission

- Thorough peer review

- No space constraints or color figure charges

- Immediate publication on acceptance

- Inclusion in PubMed, CAS, Scopus and Google Scholar

- Research which is freely available for redistribution

Submit your manuscript at www.biomedcentral.com/submit

( Biomed Central 